\title{
La liturgia como programa
}

\section{The liturgy as programme}

\author{
Esteban Fernández Cobián, Giorgio della Longa, Walter Zahner, \\ Ignacio Vicens Hualde
}

Jueves, 27 de septiembre de 2007

https://doi.org/10.17979/aarc.2007.1.0.5019

\section{Esteban Fernández Cobián}

Creo que es muy positivo que se hayan generado cuestiones polémicas, preguntas, inquietud. Desde luego, mi intervención no tenía otra finalidad que abrir completamente el abanico de los problemas que se están trabajando en la actualidad, al hilo de las cuestiones que se han venido tratando a lo largo del siglo XX y también a partir de unas definiciones — que he intentado que fueran muy precisas - de lo que se entiende por sacralidad, por liturgia y por iglesia. A partir de ahí, queda abierta la posibilidad del diálogo y de las discusiones.

Por alusiones del profesor Vicens, con el que me encanta discutir, pienso que el edificio litúrgico de la Iglesia católica es un edificio complejo, es decir: existe un dogma, algo que se cree, y ese dogma se celebra. Pero muchas veces no podemos saber qué ha sido antes: lo que se celebra o lo que se cree. A veces se celebran cosas que luego se definen como dogmas y otras veces sucede al revés. Por eso la discusión litúrgica es una discusión tan apasionante, porque toca el mismo centro de la vida de la Iglesia. Y por eso es tan difícil hablar de ello con serenidad, con tranquilidad, intentando razonar: porque es algo muy vital.

Yo he dicho en mi intervención que tanto los arquitectos como los liturgistas actuales - no recuerdo si lo dije así, tan claro- - cada uno en su campo es hijo de una revolución, es decir, de un movimiento que ha hecho una petición de principio sobre una determinada disciplina y se arroga a sí mismo la verdad absoluta. Es muy difícil que posiciones intelectuales como éstas lleguen a entenderse. Por eso es tan difícil el diálogo entre los arquitectos modernos y los liturgistas actuales.

Entiendo también que en toda materia jurídica — pienso que los documentos litúrgicos, los documentos de la Iglesia tienen valor vinculante porque tienen valor jurídico - existe una letra y un espíritu. No se puede entender la letra sin comprender el espíritu. Tampoco se puede vivir el espíritu sin conocer la letra. Ambas realidades se complementan, se enriquecen mutuamente y se hacen avanzar. Ustedes lo comprenderán perfectamente si lo trasladamos al ámbito civil. Es decir, si las leyes fueran unívocas no existirían los jueces. Toda ley es susceptible de interpretación. Las intervenciones de los jueces crean jurisprudencia y esa jurisprudencia muchas veces es determinante a la hora de fallar un juicio. Con lo cual, uno no puede acudir a la letra de una

\section{Esteban Fernández Cobián}

I believe that it is very positive that some controversial issues have been raised, questions, restlessness... Certainly, the goal of my presentation was to open a variety of problems that we are currently working with, in line with the issues which have been covered in the 20th century and also based on some definitions of what we understand by sacredness, liturgy and church: I have tried to make them quite clear:

By allusions of Professor Vicens, with whom I love to argue, I think that the liturgical building of the Catholic Church is a complex one: there is a dogma, something that people believe in, and that dogma is celebrated. However, sometimes we do not know what happened first: what you celebrate or what you believe in. Sometimes people celebrate things which are later defined as dogmas, and on other occasions it is the other way round. That is why liturgical discussions are so thrilling, because they touch upon the very core of the Church's life. That is why it is so difficult to talk about it quietly, with tranquillity, trying to reason: because it is so vital.

I said during my presentation that both current architects and liturgy experts - I do not remember whether I said it so clearly -, each in his field, are children of a revolution, that is, of a movement that made a principle request about a particular branch and that believes it possesses the absolute truth. It is very difficult to get to understand this kind of intellectual positions. That is why the dialogue between modern architects and current liturgy experts is so hard.

I also see that in every legal subject - the Church's documents are binding since they have a legal value- there is a wording and a spirit. You cannot live the spirit without knowing the wording, either. Both realities are complementary; they are enriching each other and help each other to progress. You will easily understand it if we take it to the civil level. That is, if acts were univocal, there would be no judges. Every act is susceptible of being interpreted. Judges' rulings create jurisprudence which is sometimes binding when issuing a judgment. Therefore, you cannot 
read the wording of an act without knowing what the competent authority has provided about it in the appropriate subsequent reviews, etc.

I believe that in the case of Post-council liturgical documents, this is quite clear: there are so many overlapping documents that I find myself at a loss. I do not know how I am supposed to build a church in Spain right now. I know that there were three countries, three Episcopal Conferences -Italy, Germany and USA - which took the liturgical Enchiridion and summed it up in a single document: rules for building Catholic churches in this country. I think that is great, I think that every country should have that sort of document because it is impossible to see clearly through the Enchiridion, we could keep on arguing forever. I would request the Spanish Episcopal Conference -if I knew it would be of any use - to issue that kind of document.

Well, that is all I said. Besides, I have just quoted texts by a theologian [Joseph Ratzinger] whom I consider to be relevant $-I$ believe that he undoubtedly is-, that probably he will not say exactly the same things as Pope as he did when he was a theologian - as the latter, he expressed a personal opinion, as a Pope, he must express something which is the result of a consensus, a wider thing-, although he obviously has his own personal opinion. The current Pope is a person with his own thoughts; John Paul II had a different way of thinking, just like the others had theirs. Well, that is all I wanted to add now.

\section{Giorgio della Longa}

I am sort of surplus at this panel discussion, since I am no liturgy expert. There are three architects and a theologian here. Nevertheless, I can say that I have been working for more than a decade with liturgy experts: above all in the research field, though as architect. I believe in particular, and I would like to repeat something which has already been mentioned here today, that good liturgical architecture can only come out of meeting a good architect. I think that there cannot be a good liturgical architecture without the qualitative dimension of architecture. After working with liturgy experts, for instance, taking part as contest juror, first of all I can see how the liturgy spirit of Esteban Fernández Cobián has just spoken, is hidden and degraded in what I call the liturgy engineering. A good liturgical architecture is not a good plan satisfying the liturgical rules, but it should be a space in which a liturgy is deployed: that is, architecture.

I was impressed by Professor Vicens's presentation when he referred to long and narrow plots: when you do not know what to do with that kind of plot, you give it away to build a church. I thought that was a specifically Italian scenario! In Italy, if you do not know what to do with a plot in the outskirts, you dedicate it to building a parish centre.

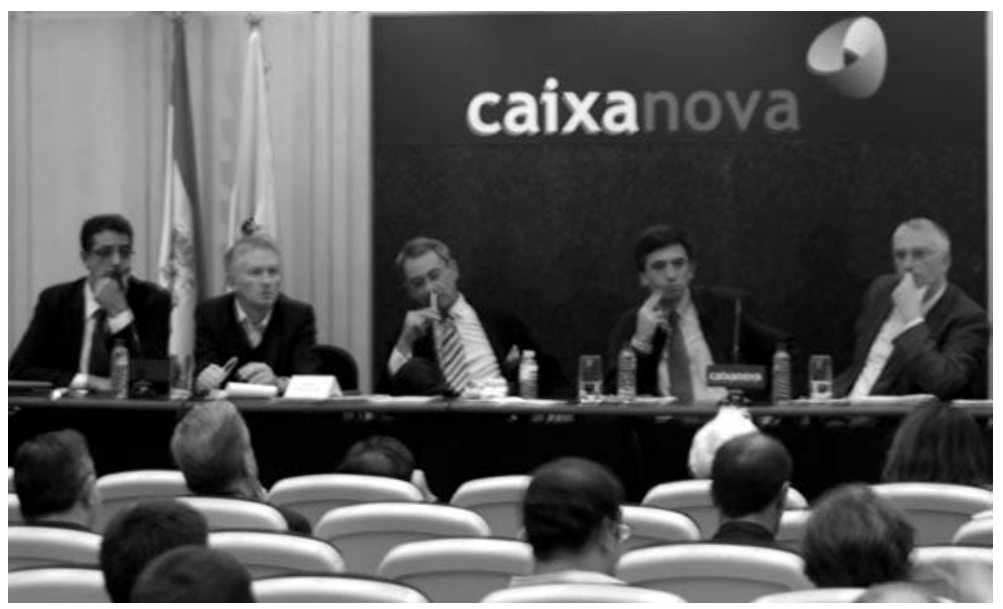

Primera mesa redonda: Xan Rodríguez (moderador), Giorgio della Longa, Ignacio Vicens, Esteban Fernández Cobián y Walter Zahner.

ley sin conocer lo que la autoridad competente ha establecido sobre ella en oportunas revisiones posteriores, etc.

Yo pienso que en el caso de la documentación litúrgica postconciliar esto es muy claro: hay tantos documentos superpuestos que yo, personalmente, me encuentro perplejo. Yo no sé cómo hay que hacer una iglesia en España ahora mismo. No lo sé. Pero sé que ha habido tres países, tres Conferencias Episcopales - Italia, Alemania y Estados Unidos-, que han cogido el Enchiridion litúrgico y lo han resumido en un documento: normas para la construcción de iglesias católicas en este país. Me parece espléndido, me parece que todo país debería tener un documento así. Porque con el Enchiridion es imposible aclararse: podríamos estar discutiendo hasta el infinito. Yo reclamaría desde aquí — si supiera que iba a valer para algo — ese documento a la Conferencia Episcopal Española.

Bien, eso es lo único que he dicho. Por lo demás, me he limitado a citar textos de un teólogo [Joseph Ratzinger] que considero relevante - me parece que lo es, sin duda-, que probablemente como papa no diga exactamente lo mismo que como teólogo - como teólogo expresa una opinión personal, como papa necesita exponer algo mucho más consensuado, mucho más amplio - aunque desde luego su opinión personal sí que existe - el papa actual es una persona con un pensamiento propio, Juan Pablo II tenía otro pensamiento distinto y Pío XII y todos los demás el suyo-. Bien, es la única matización que querría hacer en este momento.

\section{Giorgio della Longa}

Yo estoy un poco de más en esta mesa redonda: no soy un liturgista. Aquí estamos tres arquitectos y un teólogo. Sin embargo, puedo decir 
que trabajo - sobre todo en el ámbito de la investigación, aunque como arquitecto- desde hace más de diez años con liturgistas. Creo sobre todo una cosa, y con esto vuelvo a insistir en algo que ya se ha dicho aquí hoy: creo que la buena arquitectura litúrgica sólo puede nacer del encuentro con un buen arquitecto. Creo que sin la dimensión cualitativa de la arquitectura no puede nacer una buena arquitectura litúrgica. Trabajando con liturgistas — por ejemplo, participando como jurado de concursos-, en primer lugar puedo constatar cómo el espíritu de la liturgia, del que Esteban Fernández Cobián hablaba ahora, se oculta, se degrada en lo que yo llamo una ingeniería de la liturgia. Una buena arquitectura litúrgica no es una buena planta que satisfaga las reglas de la liturgia, sino que ha de ser un espacio dentro del cual se despliegue una liturgia: es decir, arquitectura.

Me ha impresionado la intervención del profesor Vicens cuando hablaba de parcelas largas y estrechas: cuando alguien no sabe qué hacer con una parcela así, la regala para hacer una iglesia. ¡Yo creía que se trataba de una situación sobre todo italiana! En Italia, cuando no se sabe que hacer con una parcela de la periferia, se dedica a la construcción de un complejo parroquial.

Ahora bien, los problemas de la liturgia nacen ya desde aquí. Porque una iglesia se presenta de una cierta manera con respecto a la ciudad — esto se ha comentado ya antes - y, por lo tanto, no se puede hablar del interior de una iglesia si no hay antes una reflexión sobre su encuentro con el exterior, con la ciudad. Y la cuestión de la liturgia es muy compleja, en mi opinión, porque hablamos de un programa, más que de un esquema. Es cierto $-\mathrm{y}$ con esto termino- que el arquitecto que se compromete con el espacio sagrado tiene que tomar decisiones: y estas decisiones deberían estar orientadas siempre por el programa enunciado en la Sacrosanctum Concilium, donde se hace una síntesis extrema de cómo debe ser la participación de la comunidad en las celebraciones sacramentales. Creo que el gran desafío que debería asumir el arquitecto es evitar interpretar, como arquitecto, el espíritu de la liturgia. Y aquí está la gran dificultad, bajo mi punto de vista: que esto no es traducible en esquemas.

\section{Walter Zahner}

Una de las reflexiones fundamentales que nos hacemos cuando vemos edificar iglesias es que los problemas se tienen que solucionar siempre con un diálogo entre el promotor - que tiene que ser la comunidad-y el arquitecto. La pregunta es: ¿quién representa a la comunidad en su diálogo con el arquitecto? Los ejemplos que les he enseñado esta mañana los he buscado conscientemente, y puedo decir que en todos ellos siempre ha habido un teólogo o un sacerdote representando a la comunidad que ha colaborado con el arquitecto. Al principio hablé de la colaboración de Romano Guardini con Rudolf Schwarz, y también diré que Albert Gehrard estuvo detrás de muchos de los proyectos que he enseñado. Es muy difícil o casi imposible que un arquitecto realice bien una iglesia
Well, this is where liturgical issues come from because a church is presented in a particular way as regards the city -it has already been mentioned - and, therefore, you cannot talk about a church interior if you do not reflect before about its relation to the outside, to the city. The liturgical issue is very complex, in my opinion, because we are talking about a programme, rather than a scheme. I would like to finish by saying that it is true that architects committed to sacred spaces must make decisions, and these decisions should be always guided by the programme quoted in the Sacrosanctum Concilium, which makes a radical synthesis of how the community should take part in sacramental celebrations. I think that the great challenge to be assumed by architects should be to avoid interpreting the liturgy spirit as an architect. The main difficulty lies here, according to my opinion that this cannot be rendered in schemes.

\section{Walter Zahner}

One of the basic reflections that we make when we witness the building of churches is that problems always have to be solved by means of a dialogue between the promoter - who must be the community - and the architect. The question is: who stands for the community in their dialogue with the architect? I have consciously looked for the examples I gave you this morning, and I can say that it was always a priest or a theologian the one representing the community and collaborating with the architect. At first I spoke about the cooperation between Romano Guardini and Rudolf Schwarz, and I will also say that Albert Gerhard was behind many of the projects that I have shown you. It is very difficult, almost impossible for an architect to make a good church if they do not have a good relationship with the person responsible for assisting them in those issues.

Although we may think that we do not know much about what church-building in Germany entails, that does not mean that architects are willing to read 30 or 40 pages before tackling a church project. I would like to give an example: I was a juror at a contest for building the new chapel of Erfurt, in Eastern Germany. The call referred to the fact that it was necessary to read the Episcopal Conference's document which was available on request. Around 100 architects expressed their interest, and approximately 55 or 60 of them delivered a project. Only two of them asked the Episcopal Conference for that text and, you may believe me, the members of the jury could tell which two had read that document. I may add, for historical background, that many of those architects from Eastern Germany had neither been raised in the Catholic faith, nor in the Protestant one, or in any other specific type of creed. This is obvious when you take a look at a project: whether the architect has really bothered to explore those issues; what is a church, what is a community, etc. 
So we chose the project by an architect who had made a Communio-Räume scheme in which the altar had a central position.

If I go back to the already shown examples, it is because Imust say that there are many communities in Germany who wish to express their idea of a community. I also have my preferences: which type or image of a community I prefer or which one I like best, however, I have tried to show them that there is no rupture between the longitudinal interpretation of a church - such as the Sacred Heart of Jesus in Munich or San Francisco or Ratisbone- and others which focus a lot more on the common celebration -the CommunioRäume scheme. There is no rupture, but a wide array of possibilities where it is striking that those communities wishing to implement the II Vatican Council's ideas always argue decisively about their idea of the liturgy. The little definition that I quoted: "the liturgy is a meeting between God and people, always starting from God and inviting people, but also uniting people among them» is really a great challenge for any architect.

For instance, with regard to the issues with Ignacio Vicens's projects, I may say that there are also those types of examples in Germany and that they should be minimised, and that is why I can understand his issue between architect and promoter. I thought that the first two projects he showed had a very clear orientation, direction, which is something really unknown in Germany, since we have very few examples. I have really liked that cooperation between space and light. I think that, in most cases in Germany, the starting point is the liturgy, maybe because there is a whole host of theologians searching for a dialogue with architects. I do not wish to give my opinion about Spain. I would just like to say that dialogue between these groups is a lot more institutional in Germany. I should also reckon that I could have shown many negative examples; anyhow, it is just something you do not do in this type of conference.

\section{Ignacio Vicens}

There is an extraordinary volume which is probably known by you: it is titled En qué creen los que no creen ${ }^{1}$ (What do non-believers believe in?). It compiles in a book the correspondence between Umberto Eco Cardinal Martini published in a Northern Italy paper. I would really like to recommend it. One of the subjects raised there is the liturgy. As opposed to Umberto Eco's practical, pragmatic attitude, Cardinal Martini is blunt in a literal sentence that I loved and have treasured in my mental library: "The Church does not satisfy expectations, it celebrates mysteries». This closes down once and for all the whole discussion about what I want, what I feel, whether the Church should do this or that, whether people should be comfortable at church, if it should foster piety, etc. The Church celebrates mysteries, that is si no tiene una buena relación con la persona responsable que le ha de ayudar en estas cuestiones.

Aunque pensemos que tenemos poca idea de lo que significa la construcción de iglesias en Alemania, eso no quiere decir que los arquitectos estén dispuestos a leer treinta o cuarenta páginas antes de realizar el proyecto de una iglesia. Quiero poner un ejemplo. Yo participé como jurado en un concurso para la construcción de una nueva capilla en Erfurt, al este de Alemania. En la convocatoria del concurso se hacía referencia a que debería leerse el documento de la Conferencia Episcopal, que se entregaría a quien lo solicitase. Se habían interesado unos cien arquitectos, y aproximadamente cincuenta y cinco o sesenta entregaron un trabajo. Solamente dos de estos arquitectos habían pedido este texto a la Conferencia Episcopal, y créanme, en el jurado podíamos decir con exactitud qué arquitectos habían leído este texto. Podemos decir, como referente histórico, que en el este de Alemania muchos de estos arquitectos no habían sido educados ni en la fe católica, ni en la protestante, ni en ningún tipo definido de creencia. $\mathrm{Y}$ esto se pone de manifiesto al ver un proyecto: si realmente el arquitecto se ha preocupado por indagar en estas cuestiones: qué es una iglesia, qué es una comunidad, etc. $Y$ entonces escogimos el proyecto de un arquitecto que había realizado un esquema Communio-Räume, en el que el altar tenía una posición centrada.

Si vuelvo a estos ejemplos que he enseñado anteriormente es porque tengo que decir que en Alemania existen muchas comunidades que tienen interés en exteriorizar su idea de comunidad. Yo también tengo mis preferencias: qué tipo o qué imagen de comunidad prefiero o me gusta más, pero aún así he intentado demostrarles que entre la interpretación longitudinal de una iglesia - como por ejemplo el Sagrado Corazón de Jesús, en Munich o San Francisco, en Ratisbona- y otras mucho más centradas en la celebración en común —el esquema CommunioRäume - , no existe una ruptura, sino un amplio abanico de posibilidades, en donde llama la atención que las comunidades que quieren realizar las ideas del Concilio Vaticano II siempre argumentan de forma decisiva lo que entienden por liturgia. Y esta pequeña definición que antes he citado - «la liturgia es un encuentro entre Dios y el hombre, siempre partiendo de Dios e invitando al hombre, pero también uniendo a las personas entre sí»— es realmente un gran reto para cualquier arquitecto o arquitecta.

Por ejemplo, haciendo referencia a los problemas de los proyectos de Ignacio Vicens, puedo decir que también en Alemania tenemos ejemplos así, que deberían ser minimizados, y por eso puedo entender su problemática entre arquitecto y promotor. Me ha parecido que los dos primeros proyectos que mostró tenían una orientación, una direccionalidad, muy clara, algo que en Alemania no conocemos realmente, pues hay muy pocos ejemplos. Y me ha gustado mucho esa colaboración entre espacio y luz. Creo que en Alemania, en la mayor parte de los casos, el punto de partida es la liturgia, tal vez porque hay un amplio abanico de teólogos 
que buscan el diálogo con arquitectos. No quiero dar una opinión sobre España. Sólo decir que en Alemania, el diálogo entre estos grupos está mucho más institucionalizado. También tengo que reconocer que podía haber mostrado muchos ejemplos negativos, pero bueno, es algo que no se hace cuando se viene a un congreso como éste.

\section{Ignacio Vicens}

Hay un libro excepcional que todos ustedes conocerán: se llama En qué creen los que no creen ${ }^{1}$. Recoge en forma de libro la correspondencia cruzada entre Umberto Eco y el cardenal Martini que fue publicada en un periódico del norte de Italia. Lo recomiendo profundamente. Uno de los temas que aparecen ahí es precisamente el tema de la liturgia. Y frente a la actitud, digamos práctica, pragmática, de Umberto Eco, el cardenal Martini es rotundo, en una frase que es literal porque me entusiasmó y la he guardado en mi biblioteca mental: «La Iglesia no satisface expectativas: celebra misterios». Esto cierra de una vez por todas ese debate de lo que quiero, de lo que siento, de que si la Iglesia debe hacer esto o lo otro, de que si en la iglesia la gente tiene que estar cómoda, confortable, si ha de excitar la piedad, etc. ¡La Iglesia celebra misterios, que es algo absolutamente maravilloso! ¡Y no satisface expectativas pequeñitas o grandes de los hombres!

Es importante esto porque no hemos hablado demasiado de misterio y es uno de los argumentos básicos de la liturgia. Y me gustaría que saliera aquí, para que no dejemos de lado un parámetro que considero importante. No hemos hablado tampoco de los signos, que creo que también son importantes dentro de la celebración del misterio. Lo dejo caer de alguna manera por si alguien está interesado y se suscitan preguntas sobre ello.

Giorgio della Longa ha estado hablando de la calidad de la arquitectura: coincido con él, y desde el principio he dejado bien claro que el valor arquitectónico de la arquitectura religiosa reside, precisamente, en su valor arquitectónico. No se puede ofrecer a Dios el sacrificio de Caín — esto está claro-: la chapuza y la vulgaridad.

De la intervención de Walter Zahner realmente confortan algunas cosas, como cuando nos hablaba de este concurso en el que solamente dos participantes de ciento veinte se habían interesado en leer las bases que daba el programa, que eran la liturgia. Nos conforta a nosotros, que siempre miramos a Alemania y a las nieblas hiperbóreas como un prodigio de aproximación intelectual. ¡Y vemos que también en Alemania et in Arcadia ego, que también allí pueden ocurrir estas cosas! En cambio, qué duda cabe, al final ha estado hablando de algo fascinante, de lo que sí tenemos que aprender: de ese diálogo, que aquí no existe, o se reduce tantísimo que, cuando lo hay, lo podemos citar como ejemplo. Ese diálogo es algo que tendremos que aprender de ellos.

Pero estamos hablando aquí, en la mesa redonda, de la liturgia como programa, y quizá sea interesante que ustedes pregunten sobre todo absolutely wonderful! It does not satisfy people's small or big expectations!

This is important since we have not spoken much about the mystery and this is one of the liturgy's basic arguments. I would like to mention it here in order to bring on board a parameter which I consider to be of essence. We have not spoken about signs, either, and I believe that they are also important within the mystery celebration. I mention them in passing, to see whether anyone is interested and has questions about them.

Giorgio della Longa has spoken about the quality of architecture: I agree with him and have made it clear from the beginning that the architectural value of religious architecture lies, precisely, in its architectural value. You cannot offer Cain's sacrifice to God, that is obvious: it is a vulgarity and $a$ hash.

From Walter Zahner's presentation, there are some comforting things, for instance when he spoke about that contest in which only two contestants out of 120 had bothered to read the basis provided by the programme, i.e., the liturgy. They are comforting to us who always gaze at Germany and its Northern shadows as a prodigy of intellectual approach. We may see that et in Arcadia ego also works in Germany, that those things can also happen there. Nevertheless, he has spoken about a fascinating thing in the end, something we should learn from: that dialogue which does not exist here or is so reduced that, when it happens, we could mention it as an example. We should learn that dialogue from them.

But in this panel discussion we are talking about the liturgy as a programme, and it may be interesting for you to ask about all that. But, first of all, I would like to say something about Esteban Fernández Cobian's presentation, with whom I have everything in common, of course, though we disagree in purely peripheral things -I do not say accidental but peripheral- that I do not wish to remain in the words. The discussion about jurisprudence, which is necessary in order to interpret the rule, leads you also to say that jurisprudence is made only by those who can: the judges. I have introduced myself here from the start as an architect making architecture. I do not need to interpret the rule, but to comply with it. I think, I guess, I am fully convinced. I do not want to interpret rules. The rules are pretty clear. It is also true that, in spite of their clarity, work is necessary. But there are no provisions clashing with others, there is no contradiction. There are great liturgy experts here, we may talk with them and there are no contradictions! But there is a chance to interpret.

Cobián said also that not only words are important, but also the spirit and this is quite clear. If you assume the spirit of the liturgical reform with that will of commitment referred to by John Paul II in the already mentioned text, then the spirit is clear: that actuosa participatio, that active participation 
which gradually leads to making more and more things has quite clear conclusions. In order to be specific, and going down to very concrete details, the debate about the altar facing the people was closed down a long time ago. If you wish to reopen, feel free to do so, but it is not open. I have already pointed out some of the things which have been clearly stated: from the General Order of the Roman Missal ( $\left.n^{\circ} 809-816\right)$ to Cardinal Lercaro's letter, the president of the Consilium, dated on 30 June 1965. He wrote quite clearly there that the vernacular language should be used, that the altar should be versum populum, and that this is the fittest for new churches. The fittest one, that's it. Only that remark forces those who wish to serve the Church as it shoud be served to say: if that is the fittest, I will do it. In Ordo dedicationis eclesiae et altaris, of 27 May 1977, you may peruse $n^{\circ} 3.758$. The Inter oecumenici instruction, in the V chapter, $n^{\circ} 91$, already quoted in $n^{\circ} 4.999$ of the Enchiridion, makes it very clear. The same thing occurs with the North American Episcopal Conference statement of 1978. And, finally, there is a relevant statement by the Pastoral Liturgical Directorate of the National Secretariat of the Liturgy in Spain... which is existent! It is true that it does not share the mandatory nature that the others have, but that Pastoral Liturgical Directorate exists since 1987. That means that there are rules in Spain since 1987. This is just to awaken controversy, which is always interesting, I guess (provided it is polite).

\section{Walter Zahner}

I would like to make a brief comment, since Ignacio Vicens has referred to many texts. In the II Vatican Council's constitution on the liturgy there are no references to the pulpit. In the 1965 instruction [Inter oecumenici] it says that two pulpits should be placed, and a couple of months later, it was corrected and said: "Well, no, one is enough».

No comment has been made about the pulpit; however, there are pulpits in many churches. Then, what to do with the pulpit in an already-existing church? There are no rules as to whether it should be used or not. That is, each community with a pulpit must reflect on how to use it. If you ask priests - and not only in Germany - if they must use a pulpit, one half would say yes and the other half would say: «I cannot use it». They all know of a particular place where it is written down.

What I mean by that is the liturgy should always be some kind of architect, though not everything has been defined to the smallest detail. There is always some scope for interpreting the texts and, I hope, also the ideas of a theologian together with the community. I would like architects to be able to convey and explain all that in their language.

\section{Esteban Fernández Cobián}

Following on what Walter Zahner has just said, as well as the speeches of the other two professors esto. Pero antes yo quisiera decir, sobre la intervención de Esteban Fernández Cobián, con el que me une todo, por supuesto, y discrepamos en cosas puramente periféricas — no digo accidentales pero sí periféricas-, que yo no quisiera quedarme en las palabras. Que la discusión sobre la jurisprudencia, siempre imprescindible para interpretar la norma, lleva también a decir que la jurisprudencia la hace solamente aquél que tiene la capacidad: los jueces. Y yo desde el principio me he presentado aquí como un arquitecto que hace arquitectura. Y que no tiene que interpretar la norma, sino cumplirla. Me parece. Creo. Estoy plenamente convencido. No quiero interpretar las normas. Y las normas están clarísimas. Es verdad que, a pesar de que están tan claras, se necesita un cierto trabajo. Pero no hay disposiciones que vayan en contra de otras: no existen contradicciones. Aquí hay grandes liturgistas, podemos hablar con ellos iy no existen! contradicciones: lo que existe es la posibilidad de interpretar.

Pero Cobián también hablaba de que no sólo la letra es importante, sino también el espíritu: se ve clarísimamente. Cuando uno acepta el espíritu de la reforma litúrgica con esa voluntad de compromiso de la que hablaba Juan Pablo II en el texto que he citado anteriormente, el espíritu es claro: esa actuosa participatio, esa participación activa que lleva a que, poco a poco, se vayan haciendo cada vez más cosas, nos conduce a conclusiones bien claras. Y para ser concreto y bajando a detalles muy concretos, la discusión sobre el altar cara al pueblo está cerrada desde hace mucho tiempo. El que quiera abrirla que la abra, pero no está abierta. He marcado aquí alguna de las cosas que están clarísimamente dichas: desde la Ordenación General del Misal Romano (nº 809-816) hasta la carta del cardenal Lercaro, presidente del Consilium, del 30 de junio de 1965. Allí deja bien claro que la lengua vernácula es la que será utilizada, que el altar debe ser versum populum y que es el más deseable en las nuevas iglesias. El más deseable, punto. Ya solamente esa indicación hace que el que quiera servir a la Iglesia como la Iglesia quiere ser servida diga: si es el más deseable lo voy a hacer. En el Ordo dedicationis eclesiae et altaris, del 27 de mayo de 1977, se puede consultar el no 3.758 . La instrucción Inter oecumenici, en su capítulo V, n ${ }^{\circ} 91$, que viene citado en este Enchiridion en el no 4.999 , deja clarísima la cosa. Lo mismo ocurre en la declaración de la Conferencia Episcopal Norteamericana, que es de 1978. Y por último, esta importante declaración del Directorio Litúrgico Pastoral del Secretariado Nacional de la Liturgia de España, que ¡existe! Es verdad que no tiene el carácter normativo que tienen las otras, pero existe ese Directorio Litúrgico Pastoral que está hecho nada menos que en 1987. Es decir, que en España, desde 1987, tenemos unas normas. Pero esto es para despertar la polémica, que siempre es interesante, yo creo (si es educada).

\section{Walter Zahner}

Voy a hacer un pequeño comentario, porque Ignacio Vicens ha hecho referencia a muchos textos. En la constitución sobre liturgia del Concilio 
Vaticano II no existe ninguna referencia sobre el ambón y el púlpito. En la instrucción de 1965 [Inter oecumenici] se dice que deberían colocarse dos ambones, y un par de meses después se corrige y se dice: — «Bueno, no, es suficiente con uno».

Sobre el púlpito no se ha hecho ningún comentario, y sin embargo el púlpito es algo que existe en muchísimas iglesias. Entonces, ¿qué se hace con el púlpito en una iglesia existente? No hay reglas sobre si se tiene que usar o si no se debe usar. Es decir, cada comunidad que posea un púlpito debe reflexionar sobre cómo usar ese púlpito. Si ustedes preguntan a los sacerdotes - y no sólo en Alemania - si se debe usar un púlpito, la mitad diría que sí y la otra mitad diría: — «No puedo usarlo». Y todos conocen un lugar concreto en el que esto está escrito.

Lo que quiero decir con ello es que la liturgia siempre debe ser una especie de arquitecta, pero no está todo claramente definido hasta el último detalle: siempre queda un pequeño ámbito de interpretación de los textos y espero que también de las ideas de un teólogo en conjunto con una comunidad. Y todo esto me gustaría que el arquitecto, con su idioma, lo pudiera transmitir y exponer.

\section{Esteban Fernández Cobián}

Al hilo de lo que acaba de decir Walter Zahner y de las intervenciones de los otros dos profesores de la mesa redonda, mañana tendremos la oportunidad de ver un vídeo de una entrevista a Álvaro Siza, a propósito de la iglesia de Marco de Canaveses. En esa entrevista, Siza dice que antes de acometer el proyecto de Marco de Canaveses pidió consejo a tres teólogos, tres liturgistas. Tuvieron varias reuniones, y él se dio cuenta de que no se ponían de acuerdo entre sí. Había un debate abierto. Él, desde luego, no estaba muy puesto en el tema -él es católico de cuando, de niño, iba a misa y poco más-, pero veía que había una discusión, algo que no había manera de conciliar entre los tres. Y entonces decidió, con su sensibilidad y con su oficio de arquitecto, acudir a la tradición portuguesa. Es decir: ¿cómo se construye una iglesia en Portugal? Pues si estos señores no son capaces de decirme cómo se construye una iglesia, yo voy a hacerla recogiendo las cosas que considero valiosas que deben tener o han tenido siempre las iglesias en Portugal. Y así trabajó él. Quiero decir con esto que ahora mismo el edificio litúrgico - el edificio normativo- es un edificio que tiene una cierta ebullición interna. Yo, desde luego no me siento autorizado para leerlo — yo no soy liturgista, ni mucho menos- pero sí que percibo esa ebullición.

\section{Participante anónimo}

Yo querría comentar un ejemplo muy concreto con una problemática muy concreta: la Catedral de Santiago, de planta de cruz latina, con un eje horizontal aproximadamente igual que el brazo largo. El altar original estaba en medio de la capilla mayor, sobre la tumba del Apóstol, con el baldaquino acompañándolo. Una situación con mucha fuerza, con mucha carga simbólica. Cuando el Concilio Vaticano II sugirió el cambio, dentro de la capilla mayor se adelantó un poco el altar, ya de cara al pueblo. Así estuvo algunos in the panel discussion, tomorrow we will have the chance to watch a video of an interview with Álvaro Siza, with regard to the Marco de Canaveses church. Siza says in that interview that, before tackling the Marco de Canaveses project, he sought the advice of three theologians, of three liturgy experts. They met several times and he noticed that they would not agree with each other. There was an open discussion. He was not an expert on the subject - he is a Catholic because he used to go to mass as a child, and little else-, but he could see that there was an argument, something upon which the three of them could not agree. Then he decided, thanks to his sensitiveness and his career as architect, to turn to Portuguese tradition. That is to say: how are Portuguese churches built? Since these gentlemen are incapable of telling me how to build a church, I will make it by compiling all those things which I consider to be useful from past or present Portuguese churches. That is how he worked. What I mean is that, nowadays, the liturgical building, the mandatory building, is a building with a certain internal turmoil. I certainly do not feel legitimated to read it - I am no liturgy expert, at all-but I do perceive that turmoil.

\section{Anonymous participant}

I would like to comment upon a very specific example with some specific problems: Santiago Cathedral, with a Latin cross plan, with a horizontal axis almost as long as the longer one. The original altar was in the middle of the main chapel, above the Apostle's tomb, with an accompanying baldachin. A very powerful scenario, with a strong symbolic load. When the II Vatican Council suggested the change, the altar inside the main chapel was brought a little forward, already facing the people. It remained thus for several years. Now it has an interim intermediate situation: so as to make it more visible from the side naves, the altar has been brought even more to the front until the start of the crossing. Not till the centre, since the censer is at the centre. In this position, the altar may certainly be seen from the sides. Some of us - me, working at the cathedral- believe that since the accompaniment of the chapel has been removed, with all those paintings, sculptures and architecture, it has lost plenty of strength, plenty of it. Now it appears to be lost, leaning on one end of the crossing. This is an interim situation: a wooden altar upon a wooden stage. They want to make a definitive one, but most of the Chapter wants to have it made of marble, for instance. However, they are not considering bringing it back again so that it stands under the shelter of the chapel dome. If you ask architects in general, they suggest that it should be moved a little backwards so that the architecture shelters and reinforces the altar. However, the Chapter prefers a good visibility from the lateral naves. Architecture does 
not matter much. This is the problem and I would like to listen to some of your opinions.

\section{Giorgio della Longa}

I am acquainted with the problem of the Santiago Cathedral, but, anyhow, it came up because the paralysis of contemporary culture as regards the past is perfectly visible there. Just to reassure you, I would say that $95 \%$ of Italian cathedrals - there is 226 of them-have temporary arrangements 40 years after the completion of the II Vatican Council.

I think that this is an underlying problem which does not only respond to this specific case. I believe that the underlying problem is precisely a cultural problem about pre-existence. When Ignacio Vicens said that nowadays you cannot escape mediocrity, that is right, because - I can see it in Italy - I have done two research works about the liturgical adequacy of Italian cathedrals, and this temporary mediocrity is the situation assumed by the upper instances because mediocrity offends nobody. That is the great offence to the Church's cultural heritage. However, unfortunately, it has been accepted by the Church, except for a few personalities out of the norm, a few cases. Please notice that people have spoken today about Cardinal Lercaro; an architect who knew Cardinal Lercaro will speak tomorrow and I do not know what he is going to say about him. But nowadays people still talk about a cardinal who was sent to the Bologna diocese 35 or 40 years ago because he was a nuisance.

However, although the diocese client -the Church - is a weak client because they do not dare to make progress with enough strength, I believe that the problem must be solved. I do not know whether I am making myself clear. I believe that the challenge facing Spanish cathedrals is hugely problematic, even if it is just for heritage; because the value of buildings - whether they are big schools, chapters, deacon's houses- practically excludes the possibility of liturgical adaptation. I think that is a general cultural problem: nowadays mediocrity is accepted, unfortunately, because it offends nobody. If excellence were to be adopted nowadays, nobody would be able to support it; nobody would take responsibility for it.

Ignacio Vicens

I totally agree, but I would like to add something else. We are living through times in which the weak thought has infected us to such an extent that, without noticing - without noticing even when we are critical about it - it pervades everything. In countries such as this one, or Italy, or so many others, where you cannot find a single cathedral which is consistent till the smallest detail, where people did not hesitate to add Baroque altarpieces to Romanesque buildings - excellent ones, both of them-; where flat Neo-classical doors had been done until the 18th century for Gothic structures, años. Ahora existe una situación provisional intermedia, en donde para que se vea mejor desde las naves laterales, el altar se ha adelantado todavía más hasta el comienzo del crucero. No hasta el centro, porque en el centro está el botafumeiro. Es una situación en la que, en efecto, el altar se ve desde los laterales. Algunos — entre ellos yo, que trabajo en la catedral- pensamos que al quitarle el arrope que le daba la capilla, con sus intervenciones pictóricas, escultóricas y arquitectónicas ha perdido mucha fuerza: mucha fuerza. Y ahora, arrimado a un extremo del crucero, está como perdido. Es una situación provisional: un altar de madera sobre una tarima de madera. Se quiere hacer definitivo, pero la mayor parte del cabildo quiere hacerlo bien: en mármol, por ejemplo. Pero no se plantean retrasarlo un poco para que vuelva bajo el cobijo de las bóvedas de la capilla. Cuando se pregunta a arquitectos en general, sugieren que hay que retrasarlo un poco para que la arquitectura cobije y de fuerza al altar, pero el cabildo se decanta por que se vea bien desde las naves laterales. La arquitectura importa poco. Existe este problema y me gustaría conocer la opinión de alguno de ustedes.

\section{Giorgio della Longa}

Conozco el problema de la Catedral de Santiago, pero de cualquier manera ha surgido porque en él se ve exactamente cuál es la parálisis de la cultura actual respecto a la del pasado. Para tranquilizarle, debo decir que el noventa y cinco por ciento de las catedrales en Italia — que son doscientas veintiséis - tienen adecuaciones provisionales a los cuarenta años de haber terminado en Concilio Vaticano II.

Yo creo que el problema es un problema de fondo, que no sólo responde al caso de este problema específico. Pero creo que el problema de fondo es precisamente un problema cultural sobre las preexistencias. Cuando Ignacio Vicens decía que hoy no se puede salir de la mediocridad es exacto, porque $-\mathrm{y}$ yo lo veo en Italia: he realizado dos trabajos de investigación precisamente sobre la adecuación litúrgica de las catedrales italianas - la mediocridad provisional es la situación que se ha aceptado desde las instancias superiores: porque lo mediocre no molesta. Esa es la gran ofensa al patrimonio cultural de la Iglesia. Sin embargo - y desgraciadamente - , ha sido aceptada por la Iglesia, salvo escasas personalidades que se salen de lo normal, pocos casos. Fíjense: habrán notado que hoy se ha hablado del cardenal Lercaro; mañana hablará un arquitecto que ha conocido al cardenal Lercaro y no sé que cosas dirá sobre él. Pero hoy se sigue hablando de un cardenal al que hace treinta y cinco o cuarenta años se le envió a la diócesis de Bolonia porque era incómodo.

Sin embargo, creo que hoy, aunque el comitente diocesano - la Iglesia - sea un comitente débil porque no arriesga en avanzar con la fuerza debida, el problema deberá resolverse. No sé si me estoy explicando. Creo que el reto de las catedrales españolas es enormemente problemático, aunque sólo sea para el patrimonio, porque el valor de los edificios — sea el caso de las grandes escuelas, de los cabildos, de los diaconías - prácticamente excluye la posibilidad de la adecuación litúrgica. Creo que es un problema cultural general: que hoy, por desgracia, se acepta la mediocridad porque, 
en el fondo, es lo que no molesta a nadie. Y si hoy se adoptase la excelencia, nadie sería capaz de sostenerla, de responsabilizarse de esa excelencia.

\section{Ignacio Vicens}

Estoy totalmente de acuerdo, pero quisiera matizar otra cosa también. Vivimos en una época en la que el pensamiento débil nos ha contaminado de tal manera que sin darnos cuenta — sin darnos cuenta incluso aunque seamos críticos con él- nos empapa. En un país como el nuestro o como Italia o como muchos otros en los que no es posible encontrar una sola catedral coherente hasta el último detalle, en los que sin ningún tipo de miedo se han introducido retablos barrocos en edificios románicos, excelentes ambos; en los que hasta el siglo XVIII se hacían puertas llanas neoclásicas en estructuras góticas, como en la Catedral de Toledo; en donde cada época, con seguridad en sí misma y con la voluntad de cantar a Dios en su propio idioma, era capaz de intentar hacer lo mejor sin ningún tipo de miedo, hoy hemos caído en el paura l'sbaglio, el miedo a equivocarnos, porque todos estamos inficionados en ese pensamiento débil. Creo que era Heine, el que un día, paseando cerca de la Catedral de Colonia, le comentó a un amigo:

- ¿Cómo es posible que nuestros antepasados hicieran estas maravillas y nosotros sólo seamos capaces de acometer pequeñas intervenciones?

- Mi querido Heinrich - le contestó el otro-: nuestros antepasados tenían certezas, y nosotros, sólo opiniones.

¿Por qué seguimos construyendo estructuras provisionales en las iglesias cuarenta años después del Concilio? Porque seguimos con miedo a equivocarnos. Porque no tenemos certezas. Porque no queremos amar lo que la Iglesia nos dice. ¡Si la Iglesia es extraordinariamente comprensiva! Hay toda una serie de directorios para actuar: por supuesto en las iglesias nuevas, pero también en las antiguas, donde se nos dice: - Ni se os ocurra tocar las cosas buenas que hay. No hay por qué quitar los altares maravillosos. Es verdad que nos dicen que sólo puede haber un altar, para que quede claro que sólo puede haber un lugar de sacrificio. Ya no existen los otros. Pero ni se os ocurra tocar los altares maravillosos que los siglos precedentes hicieron. Dejadlos como objetos, no como altares. Quitadles los manteles. No les pongáis flores, ni velas ni cristos ni nada. Que queden como objetos bellos, pero no como altares.

La polémica con el púlpito, algo obsoleto hoy en día cuando existen los micrófonos - que casi siempre funcionan-y por lo tanto no hay que ponerse en el centro de la iglesia para que la gente oiga, está en esa misma línea. Si el púlpito es un objeto bellísimo - cualquiera de esos púlpitos barrocos maravillosos-, no se puede tocar: es un objeto. Pero no tiene sentido, cuando se puede hablar con un micrófono sin moverse del sitio. Lo importante es amar lo que se nos dice y acometerlo sin miedo, con la convicción de que eso funciona. Y entonces no nos equivocaremos, como no se equivocaron los que introdujeron retablos barrocos en la Catedral de Santiago o en las demás catedrales. ¡Y mira que era bueno lo que tenían antes! such as at the Toledo cathedral; where people from each epoch, self-confident people wishing to praise God in their own language, were capable of trying to do their best without any kind of fear; nowadays we have fallen into paura l'sbaglio, the fear of making mistakes; because all of us are infected by that weak thought. I believe it was Heine, who once told a friend while taking a stroll along Cologne cathedral:

- How is it possible that our ancestors built these wonders while we can only tackle small interventions?

- Dear Heinrich - answered the other one-: our ancestors had certainties while we just have opinions.

Why are temporary structures still built in churches 40 years after the Council? Because we are still afraid of making mistakes, because we have no certainties, because we refuse to love what the Church is telling us. But the Church is extraordinarily understanding! There is a whole series of guidelines for action: of course, for new churches, but also for the old ones. They are telling us: dare not touch the already-existing good things. There is no reason to remove those wonderful altars. They certainly tell us that there can be only one altar, so as to make it clear that there can only be one place for the sacrifice. There are no others anymore. However, do not dream of removing the wonderful altars made during past centuries. Leave them as objects, instead of altars. Remove the tablecloths. Do not place flowers, candles or Jesus Christ, nothing. They must remain as beautiful objects instead of altars.

About the pulpit controversy, which is obsolete nowadays when there is a PA system-usually operative-, therefore there is no need to stand at the church centre so as to be heard by people, it goes along the same line. If the pulpit is an incredibly beautiful object - any of those wonderful Baroque pulpits-, then it cannot be touched: it is an object. However, it makes no sense when you can speak through a microphone on the spot. The important thing is to love what you are told and to face it fearlessly, with the conviction that it works. Then we will make no mistakes, just like those who added Baroque altarpieces to Santiago cathedral or anywhere else did not make a mistake. And what a good thing they already had!

Carles Elías

I am a priest from the Barcelona diocese currently based in San Feliu de Llobregat. I studied architecture, I worked as an architect for a few years and I also studied liturgy. For those reasons, my concern is treble: as a pastor - the bishop's aid or collaborator-, as a liturgy expert and as an architect. I think that dialogue is hard; it is rather complicated, like Esteban Fernández Cobián has said. We all believe that we are right. Architects are a bit as a pharaoh, sometimes you sense some 
kind of despotism in those who have the upper hand, particularly in those who pay - as we say in Catalonia: if you pay, you order-; and that makes it very hard to have quality works.

According to my experience, there is little architectural quality, too much liturgical confusion - people do not know the liturgy well-and, on top of that, with the usage given to churches, things do not work out because there is a lack of pastoral practice. That is, sometimes liturgy experts are theoreticians; architects do not understand religious practices either, so things must be corrected daily: issues of adequacy to use. I have requested some dialogue and I have been wondering what you can do so as to foster that dialogue, so as to get some results which are not, at least, disastrous. Because it is people who pay in the end -the bishopric and the people- and damage is visible and you need to undo things so as to rebuild them again, so people have to pay for it again. I believe that what has been said about mediocrity is real and that some mechanisms must be found in order to achieve some more rigour, coherence and accurateness in things.

Some things are clear: for example, polycentrism. The Council's provisions state that the altar must be the focus where people's attention naturally converges. It is very difficult to achieve what $\mathrm{Mr}$. Vicens has said: there are many foci but there has to be a priority one, which is the altar. There are so many issues around which people are confused. There has to be an engine, somebody saying: it is so. I do not know if you understand it.

\section{Miguel Ángel González}

This is a very interesting dialogue among liturgy experts and architects, and I wonder: what is the role of the temple user? What is going on? I can see a huge problem, a very serious problem with training and education: mediocrity is accepted as a wonderful thing. Even in the parishioners' own lives, in everything they use, there is mediocrity. Here, in these fields where we are detached from the cultivated elites, the solutions provided cause no problem because people like vulgar things; unfortunately... Olot is still very popular here! Contemporary art - particularly in the adaptations, in those actions which should be faced with a certain will of making them more upto-date, of not fearing them- this always clashes with people, since they will reject them. I could quote some clarifying cases. I would even say that priests' training was very limited, given that bishops themselves had rather mediocre tastes. Those tastes were rendered into the seminarians education: there was no subject for that training at seminars. This whole problem dates from a long time ago and it has no simple solution. When somebody tries to do something which is really upto-date, that will be rejected. This is a sad thing. For that reason, we still encounter today some actions in churches of the 21st century which plan

\section{Carles Elías}

Soy un sacerdote de la diócesis de Barcelona que actualmente vivo en San Feliú de Llobregat. Estudié arquitectura, trabajé como arquitecto unos años y también estudié liturgia. Por eso tengo una triple preocupación: como pastor - como ayudante o colaborador del obispo-, como liturgista y como arquitecto. Creo que el diálogo es difícil, es bastante complicado, como decía Esteban Fernández Cobián. Todos nos creemos con razón. El arquitecto es un poco faraón; a veces se ve un poco de despotismo en los que mandan, sobre todo en los que pagan — como decimos en Cataluña, el que paga manda-; y así es muy difícil que los trabajos sean de calidad.

Mi experiencia es que hay poca calidad arquitectónica, bastante despiste litúrgico — no se conoce bien la liturgia - y después, con el uso que se da a las iglesias, no acaban de funcionar bien las cosas porque falta la práctica pastoral. Es decir, que a veces los liturgistas son teóricos, los arquitectos tampoco comprenden mucho la práctica religiosa, y luego en el día a día hay que corregir temas, temas de adecuación a los usos. Claro, yo reclamaba esto: que hubiera un diálogo. Y me preguntaba cómo se podría hacer para fomentar ese diálogo, para que luego los resultados como mínimo no fueran desastrosos. Porque al final la que paga es la gente -el obispado y la gente-, y los daños quedan a la vista y hay que deshacer las cosas y volverlas a hacer nuevas. $\mathrm{Y}$ eso lo tiene que volver a pagar la gente. Y me parece que lo que comentamos de la mediocridad es real y que se tendrían que buscar mecanismos para que hubiera un poco más de rigor, de coherencia y de exactitud en las obras.

Y hay cosas que son claras. Por ejemplo, lo del policentrismo. Las disposiciones del concilio dicen que el altar ha de ser el foco donde converja de forma natural la atención de la gente. Y es muy difícil realizar lo que decía usted, Vicens: que hay muchos focos pero ha de haber un foco prioritario, que es el altar. Y así tantos temas en los que hay una cierta confusión. Hace falta alguien que empuje, que diga: esto es así. No sé si me explico.

\section{Miguel Ángel González}

En este diálogo tan interesante entre liturgistas y arquitectos me pregunto dónde queda después el usuario del templo. ¿Qué pasa? Yo veo un grave problema, un gravísimo problema de formación y de educación: que se acepta la mediocridad como una cosa maravillosa. Porque en la propia vida de esos feligreses, en casi todo lo que usan, existe la mediocridad. Y aquí, en estos ambientes en los que estamos alejados de esas élites más cultas, las soluciones que se han dado no causan problema porque a la gente le gusta, por desgracia, lo vulgar... ¡Olot sigue teniendo aquí un éxito tremendo! Y el arte contemporáneo - sobre todo en la adaptación, en esas actuaciones que se deberían acometer con una cierta voluntad de hacerlas actuales y de no tener miedo a ellas - choca enseguida con la gente, que las rechaza. Se podrían contar algunos casos que serían esclarecedores. Incluso yo diría que la formación de los propios sacerdotes ha sido muy limitada, porque los mismos obispos tenían unos gustos mediocres. Y esos gustos se han traducido en la educación de los seminaristas: no existía ninguna asignatura en los seminarios para formarlos. Todo eso es un problema que viene de atrás 
y que no se puede resolver fácilmente. Y cuando alguien intenta hacer algo verdaderamente actual, encontrará un rechazo. Y es triste que así sea. Y por eso nos seguimos encontrando con actuaciones en iglesias que hoy, en el siglo XXI, siguen planteando unos ornitorrincos compuestos de un altar neorrenacentista, un sagrario neorrománico, un santo de pacotilla, unas cosas espantosas pero que parece ser que tienen la aprobación de los que la encargan y de los que las usan. Este es un problema que es complejo, pero creo que también debería valorarse a la hora de ir enriqueciendo todo este planteamiento de cómo la belleza debería estar más metida en nuestra vida, y no quedarse solamente en las teorías.

\section{Ignacio Vicens}

Quisiera decir algo. Creo en el valor formativo de la liturgia. Cuando se explica a la gente la diferencia que existe entre la sede, que es el lugar donde el sacerdote, cuando está presidiendo, convoca a la asamblea de los fieles; el ambón, que es el lugar donde se lee la palabra de Dios — idonde se lee la palabra de Dios!, no donde se dice «mañana tendremos nosequé, reunión de jóvenes...»): eso, desde otro sitio-; cuando se vive bien la liturgia y se utiliza el ambón sólo para proclamar la palabra de Dios, no la interpretación que pueda hacer otro ni siquiera para dar los avisos que hay; cuando después se llega al momento en que toda la atención se concentra en el altar - que, efectivamente, debe ser el centro del espacio - y empieza lo verdaderamente nuclear, una vez que ya nos hemos calentado - perdón por la expresión: estoy hablando como si estuviera hablando a mis alumnos, a los que hay que explicarles las cosas con este lenguaje tosco, deportivo, pero que es el único que pueden entender-, eso es extraordinariamente didáctico. Entienden el sacrificio de la misa, que no es solamente un sacrificio, sino que también es muchísimas cosas más: es una realidad muy compleja, porque también está la eucaristía, además del sacrificio, también está la lectura de la palabra de Dios... Esa cosa tan compleja se la damos masticada, se la damos separada.

¿Dónde está la gente aprendiendo? Yo confío en el poder de la liturgia para enseñar a la gente. Y no me interesan en cambio nada, inada!, aproximaciones del tipo me gusta-no me gusta, excitar su piedad o no... ¿Cómo podemos intentar, por favor, a estas alturas del partido, intentar excitar la piedad de los fieles, es decir, intentar que ante una determinada realidad como es el arte sacro de una iglesia haya reacciones unánimes de gente tan radicalmente diferente como es el pueblo de Dios, que es lo más proteico que existe?: intelectuales, amas de casa — que son también intelectuales en muchos casos-, labradores, jóvenes y viejos... ¡todo el mundo es pueblo de Dios! ¿Cómo podemos pretender que todo el mundo tenga las mismas reacciones ante un hecho tan complejo como es la arquitectura? Abandonemos todo eso. No pensemos en qué piensan los demás. Ofrezcámosles lo que la Iglesia ofrece: una liturgia que es parlante y que enseña. Y que es didáctica. Yo creo en el valor de la liturgia. Eso es lo que debemos ofrecer.

\section{Walter Zahner}

Quiero citar dos ejemplos que, por supuesto, no son generalizables. El primero es la Catedral de Münster, en Westfalia. En la Segunda Guerra some duck-billed platypus consisting of a NeoRenaissance altar, a Neo-Romanesque tabernacle, a slapdash saint plus some terrible things which seem to be approved by the commissioners and the users. This is a complex problem, but I believe that it should be considered when trying to foster this approach according to which beauty should be a greater part of our loves, and not just a theory.

Ignacio Vicens

I would like to say something. I believe in the training value of the liturgy. When you explain to people the difference between the see, which is the place where the presiding priest calls the assembly of the faithful; the pulpit, which is the place from where God's words are read - where God's words are read!, not where you say there is a do tomorrow, youth meeting, whatever... that should be done somewhere else-. When the liturgy is well lived and the pulpit is only used for reading out God's words, not somebody's interpretation, even for giving announcements; when the moment when the whole attention is focused on the altar arrives - which must certainly be the centre of spacewhen the core thing starts, after the warming - up-forgive my expression, I am speaking as if I was addressing my students, you need to explain things to them in this crude, sporty language, since it is the only one they can understand-, that is extraordinarily pedagogical. They understand the sacrifice of mass, which is not just a sacrifice, but many other things: it is a very complex reality, since the Eucharist is there too, apart from the sacrifice; there is also the reading of God's words... All that complex stuff is pre-digested for them, separately. Where are people learning? I trust in the power of the liturgy for teaching people. I am not at all interested in statements such as: I like it, I don't, moving them to piety or not... How can we, at this stage of the game, try to move the believers to piety, i.e., to try to elicit unanimous reactions from such radically different people before the sacred art of a church, when God's people are the most protean thing that there is? We are talking about intellectuals, housewives - sometimes intellectual housewives-, peasants, young and old... Everybody is God's people! How can we expect everyone to react in the same way to something as complex as architecture? Let us forget all that. Let's not think about what the others are thinking. Let's offer them what the Church has to offer: a talking and teaching liturgy, a pedagogical one. I believe in the value of the liturgy and that is what we should offer.

\section{Walter Zahner}

I would like to quote a couple of examples which cannot be generalised, of course. The first one is the Münster cathedral, in Westphalia. Most of it was destroyed in the II World War and it had to be reconstructed and opened in the mid 50s. The bishopric called a small contest in which people like Rudolf Schwarz \& Emil Steffan took part. The 
contest was won by Emil Steffan, who started a dialogue with the bishop. His key idea was that the cathedral was the bishopric centre. Every priest would be consecrated there and would be sent to their corresponding communities from there. Was it possible to rebuild that cathedral in 1951 or 1952 the way it was before, i.e., placing the altar at the previous position, away from people or should they do as the liturgy and Pope Pio XII were proclaiming: that the liturgy should constitute the centre of humankind and of Jesus Christ's death and resurrection? If the liturgy was the centre, then it had to be at the centre of humankind, of people: also at the centre of a cross plan.

The Cathedral Chapter was split in half: they could not make a clear decision. Then the bishop said: These are the 50s and we want the altar, i.e., Christ, to be at the centre of our church. Let us remember that it was in 1952, and this caused a certain disagreement among the bishops. A few years later, the other cathedrals, around 30 of them, were rebuilt in the same fashion. The Münster bishopric had been a pioneer in that time and had acted as a role-model. They said that he was a progressive bishop and he was so lucky to have it made exactly thus. However, what he had done was to materialise the basic thought of the liturgy.

I will now explain the second example more briefly: Saint Jude Thaddeus church in Karlsruhe, which I have already shown you. Ottokar Uhl completed it 10 years after the contest. It was not a money issue, or a matter of quarrels or lack of acceptance of his project: the architect wanted the community members to take an active part in the expression and materialisation of this church. This took a period of 6 or 7 years, given that it was (and still is) a very conservative community. Actually, this is a church which lacks an open or a closed ring plan, because a great part of the community members were of Russian origin; very simple people who would not assume that sort of expression. So the architect took his own time and, I cannot give you an exact number, but I guess that he organised around 100 meetings so as to discuss with the community members. Every week he would meet a different group of people and, finally, he managed to encourage and convince the members of this community. Naturally, this was only possible because he had the support both of the bishopric and the priest. If he had wanted to get this building done in a quick, precise and decided way, he would have never achieved it. Or maybe it would have become a church without community. His idea of participation was very complex, but I guess that the solution shows that the effort was worth it; which is something that cannot be achieved always and everywhere.

Ramiro González Cougil

Having listened to the lectures this morning and afternoon, I would like to take part a little bit in this dialogue from the viewpoint of the liturgy.
Mundial se destruyó en gran parte, y a mediados de los años cincuenta debía ser reconstruida y abierta. El obispado convocó un pequeño concurso en el que, por ejemplo, participaron Rudolf Schwarz y Emil Steffan. Este concurso lo ganó Emil Steffan, que comenzó un diálogo con el obispo. Su idea central era que la catedral era el centro del obispado. Aquí se consagrarían todos los sacerdotes y desde aquí irán a sus respectivas comunidades. ¿Se podía, en 1951 ó 1952, reconstruir esta catedral tal como estaba antes, es decir, por ejemplo, colocar el altar en su posición inicial, lejos del pueblo, o se debería, por el contrario, realizar lo que la liturgia y el papa Pío XII proclamaban: que la liturgia debería ser el centro de la humanidad y de la muerte y resurrección de Cristo? Si la liturgia era el centro, tenía que estar en el centro de la humanidad, de los hombres: también en el centro de una planta en forma de cruz.

El cabildo de la catedral estaba dividido al cincuenta por ciento: no podía tomar una decisión clara. Entonces el obispo dijo: - Estamos en los años cincuenta y queremos que el altar, es decir, Cristo, esté en el centro de nuestra iglesia. Recordemos que era el año 1952, y esto provocó una cierta desavenencia con otros compañeros también obispos. Al cabo de unos años, las otras catedrales, aproximadamente treinta, fueron reconstruidas del mismo modo. El obispado de Münster se había adelantado un poco a su tiempo y había actuado de forma ejemplar. Se decía que era un obispo progresista, y tuvo mucha suerte de que esto se realizase exactamente así. Pero en realidad lo que había hecho era materializar el pensamiento básico de la liturgia.

El segundo ejemplo voy a exponerlo de forma más breve: la iglesia de San Judas Tadeo, en Karlsruhe, que he enseñado. Ottokar Uhl la terminó diez años después del concurso. No se trataba de una cuestión de dinero, ni de una cuestión de disputas o de no aceptación de su proyecto: el arquitecto deseaba que los miembros de la comunidad participasen de forma activa en la expresión y en la materialización de esta iglesia. Y esto llevó un periodo de tiempo de seis o siete años, porque esta comunidad era y es muy conservadora. En realidad es una iglesia que no tiene ni una planta abierta ni de anillo cerrado, porque gran parte de las personas que formaban parte de esta comunidad era gente que había venido de Rusia; gente muy sencilla, que no podía asimilar este tipo de expresiones. Pero el arquitecto se tomó su tiempo $\mathrm{y}$, no podría decir un número exacto, pero diría que realizó aproximadamente cien reuniones para dialogar con los miembros de esta comunidad. Cada semana se reunía con un grupo diferente de personas, y al final consiguió animar y convencer a esta comunidad. Y naturalmente, esto sólo fue posible porque tanto el sacerdote como el obispado le prestaron todo su apoyo. Si él hubiese querido realizar esta construcción de forma rápida, precisa y decidida, nunca lo hubiese podido hacer. O se hubiese convertido en una iglesia que no tendría comunidad. Su idea de participación era muy compleja, pero creo que la solución demuestra que realmente el esfuerzo ha valido la pena, algo que no siempre, ni en cualquier parte, puede realizarse.

\section{Ramiro González Cougil}

Después de haber oído esta mañana y por la tarde las conferencias, yo quisiera participar un poquito de este diálogo desde el punto de vista de 
la liturgia. Soy doctor en liturgia por la Universidad de San Anselmo, de Roma, y quisiera agradecer al profesor Vicens que haya explicado muchos aspectos en los que ese diálogo liturgia-arte es muy importante. Y ahora al final, agradecerle esta afirmación que ha hecho de que la liturgia educa $\mathrm{y}$ forma.

De algunos puntos que he oído, destacaría la importancia de la liturgia desde el punto de vista del misterio: que cuando de verdad se tiene el sentido del misterio, las cosas cambian, también para el arquitecto. Y decir misterio no quiere decir una cosa absolutamente incomprensible, sino que quiere decir algo a lo que se accede por la fe. Veo muy difícil que una persona que trabaja con las formas, con los elementos, etc., pueda llegar desde una actitud indiferente o desde una actitud de no creencia a una realización que sea significativa para el que tiene fe. Me parece que eso es fundamental.

Cuando ustedes han aludido a algunos elementos de la liturgia, me parece que ahí habría que destacar, por ejemplo, la participación activa como algo querido por la constitución Sacrosanctum Concilium y todos los demás documentos de la reforma del Concilio Vaticano II. Pero también hay otros aspectos que no se deben olvidar, como por ejemplo los ministerios, los signos, los símbolos — también ustedes han aludido a ellos - o la asamblea. Y debemos distinguir mucho lo que es de Dios, que es lo primero en la liturgia. Es decir, en la liturgia la iniciativa siempre la toma Dios, y el hombre simplemente responde ayudado por la fe y por la gracia. Creo que eso es también decisivo a la hora de plasmar en la arquitectura lo que los documentos afirman.

Sobre ese tema de que hay muchos documentos que dan la impresión de que se oponen unos a otros, yo también creo, con el profesor Vicens, que no se oponen, sino que la Iglesia va caminando con los hombres y, lógicamente, va descubriendo cosas. Y por tanto, hay momentos en los que no lo tiene del todo claro, pero hay otros momentos en los que determinadas cosas ya las puede señalar como doctrina firme. Y eso está en los documentos. Por ejemplo, en la Ordenación General del Misal Romano hay afirmaciones que no estaban en la primera edición: después de varias ediciones algunas cosas se han corregido, otras se han añadido. Quiero decir con esto que la Iglesia no renuncia - todo lo contrario - a la creatividad. En materia de arte y de belleza la Iglesia no está cerrada a ninguna forma, a ninguna, siempre que esté en el espíritu de la liturgia, que ustedes han comentado partiendo de Guardini, aunque también hay otras personas que, desde Guardini, han profundizado en eso.

Termino con el ambón. El tema del ambón está muy claro en la Ordenación General del Misal Romano: que no debe haber dos ambones, que una cosa es el atril y otra cosa es el ambón, que el ambón es únicamente para la palabra de Dios - lo ha dicho también el profesor Vicens- y el atril es un instrumento que ayuda en otros momentos. Pero igualmente habría que destacar la sede y el altar. El altar tiene una importancia tan grande en la celebración litúrgica que antes y durante la celebración es el
I have a PhD in Liturgy by the San Anselmo University of Rome, and I would like to thank Professor Vicens for explaining many aspects where the dialogue between liturgy and art is very important. I would also like to thank him for his final point that the liturgy trains and educates. As regards some of the opinions I have heard, I would point out the importance of liturgy from the viewpoint of mystery: if you really possess the sense of mystery, things change, also for the architect. When I say mystery, I do not refer to something which is incomprehensible, but to something that can be accessed through faith. I think that it is very hard for a person working with shapes, with elements, etc., to achieve from an indifferent attitude or from a lack of belief something which is significant for the faithful. I believe that is of essence.

You have mentioned some examples out of the liturgy, and I think that it is worth pointing out that, for example, an active participation is desired by the Sacrosanctum Concilium constitution and all the rest of reform documents by the II Vatican Council. There are other aspects which should be remembered, for instance, the ministries, the signs, the symbols - you have also referred to them-or the assembly. We should also distinguish what God is; he is the first thing in the liturgy. That is, God is always the one taking the lead in liturgy, and people simply respond aided by faith or grace. I think that is also decisive when portraying in architecture what the documents state.

With regard to the issue that there seem to be many documents opposed to the rest, I agree with Professor Vicens that they are not opposed, but the Church walks along with human beings and, as a result, it finds out things. Therefore, there are times when not everything is totally clear, while on other occasions, some things can be defined as a clear doctrine. That is in the documents. For instance, there are statements in the General Ordination of the Roman Missal which were not there in the first edition: after several editions, some things have been amended and others added. I mean to say that the Church does not reject creativity, on the contrary. In matters of art and beauty, the Church is not closed to any form, no way; provided it is in line with the liturgy spirit which you have mentioned based on Guardini; although there are others who have deepened that approach since Guardini.

I will finish by talking about the pulpit. The pulpit issue is very clear in the General Ordination of the Roman Missal: that there should not be two pulpits; that one thing is the rostrum and another thing is the pulpit; that the pulpit is only for God's words - Professor Vicens has also mentioned that-and the rostrum is a helpful tool for other occasions. You should also distinguish between the see and the altar. The altar is so important in liturgical celebrations that it constitutes the central spatial point before and during the celebration. It even surpasses -and this is no 
heresy- Jesus Christ's real presence in the Eucharist reserve which, ideally, should not be in the same space during the liturgical celebration. You have also spoken about directories. There are some things which the Church has been working on and which are unknown. There are many specific directories with that doctrine which admits many variants itself; that is, the pulpit can be placed in many places around the church, the altar can also be at various points, the same goes for the see. However, the Church praxis has determined, has specified the places where it cannot be. Maybe we ignore or we should study the places where it can be, but certainly we know where it cannot be. Of course, many of these things can be said with absolute clarity. There could be many aspects to discuss, but I would like to invite you to talk about these issues.

\section{Giorgio della Longa}

The problem lies precisely in the dialogue with the community. Walter Zahner has said, with good reason, that the dialogue with the community is constitutive. I believe that every architectural project may be born out of the meeting between the client and the project maker. I do not think that the client or the architect make the church. An architect who makes his home does not exactly manage to make his home. However, I guess that German communities are very small, and maybe that reduced size has increased quality. On the opposite side, the average quality of Italian communities is very poor. When we worked with liturgy experts, we had no community representatives. They do not know what to talk about. This discourse is alien to them, except for a few exceptions. Some bishops or dioceses do not accept the aesthetic dimension in their own pastoral experience: it does not exist; it has not existed for many years.

I would like to illustrate that difficult dialogue with a personal example. You have referred to the pulpit. I have taken part in a pilot project for the liturgical adequacy of Ravenna cathedral; a project made with a commission appointed by the bishop. The bishop wanted a new pulpit. However, at Ravenna cathedral there is a gem of a pulpit: it is called the Agnello Pulpit, from the 6th century; it has a double staircase measuring $2 \mathrm{~m}$, with a double loudspeaker. So I said: As an architect, I will not make a project for a new pulpit. Do you know what the bishop answered? He told me: I use the pulpit on Easter evening. OK, I said. He said: Nevertheless, when I preach from the pulpit, the believers end up with a pain in their necks because the pulpit is in the middle of the church. That is the problem, or one of them... punto central del espacio, incluso - y esto no es una herejía- sobrepasando a la presencia real de Jesucristo en la reserva eucarística que, como ideal, en el momento de la celebración litúrgica no debería estar en el mismo espacio.

Se hablaba también de los directorios. Hay cosas que no se conocen, pero que la Iglesia ha ido trabajando. Hay muchos directorios muy concretos con esa doctrina que de suyo admite muchas variaciones, es decir, el ambón se puede poner de muchas formas en la Iglesia, el altar puede estar en distintos puntos, la sede lo mismo. Pero después, la praxis de la Iglesia ha ido determinando, ha ido concretando, por ejemplo, en qué sitios no puede estar. A lo mejor no sabemos o tenemos que estudiar en qué sitios sí puede estar, pero desde luego ya sabemos en qué sitios no. Desde luego, muchas cosas de ese tipo se pueden decir con cierta claridad. Habría más aspectos que comentar, pero yo invitaría a que dialogásemos sobre estos temas.

\section{Giorgio della Longa}

El problema es precisamente el del diálogo con la comunidad. Walter Zahner ha dicho, con muy buen criterio, que el diálogo con la comunidad es constitutivo. Y yo creo que todo proyecto de arquitectura puede nacer tras un encuentro entre un comitente y un proyectista. No creo que el comitente haga la iglesia ni que el arquitecto haga la iglesia. El arquitecto que hace su casa no consigue propiamente hacer la casa. Sin embargo, pienso que en Alemania las comunidades son muy reducidas, y tal vez esa reducción de tamaño ha aportado mucha calidad. En Italia, por el contrario, la calidad media de las comunidades es muy baja. Y cuando nosotros hemos trabajado con liturgistas, no teníamos ningún representante de la comunidad. No saben de qué hablar. Es un discurso ajeno a ellos, salvo muy contadas excepciones. Y hay obispos o diócesis que no admiten la dimensión estética en su propia experiencia pastoral: no existe, no ha existido durante muchos años.

Quiero ilustrar ese difícil diálogo con un ejemplo personal. Se han referido al ambón. Yo he participando en un proyecto experimental de adecuación litúrgica de la Catedral de Rávena, un proyecto hecho con una comisión nombrada por el obispo. El obispo quería un nuevo ambón. Pero dentro de la Catedral de Rávena hay un ambón que es una joya: se llama ambone di Agnello, es del siglo VI, tiene una escala doble, dos metros de alto, con un tornavoz también doble. Yo dije: —Como arquitecto, yo no proyecto un nuevo ambón. ¿Saben, finalmente, cual fue la respuesta del obispo? El obispo me dijo: - Yo uso el ambón la noche de Pascua. —Bien, le dije. - Sin embargo, cuando predico desde el ambón, todos los fieles acaban con dolores en el cuello, porque el ambón está en mitad de la iglesia. Este es el problema, es uno de los problemas... 